\title{
The Space for Restorative Justice in the Ethiopian Criminal Justice System
}

\author{
ENDALEW LIJALEM ENYEW*
}

\section{Introduction}

Restorative justice views criminal conflict as an injury or violation of the relationship between victims, offenders and community members, ${ }^{1}$ and the 'property' of those involved in the conflict. ${ }^{2}$ It complements the criminal justice system with the aim to heal the injuries of all parties involved in criminal conflict: victim, offender and community. Instead of merely focusing on punishment, restorative justice processes contribute to the re-integrative aspect of shaming. Moreover, restorative justice processes provide victims a central role in the process and help meet their need for information about the reasons for the crime and the circumstances of its commission. Such processes also allow for the victims to be heard, which may in turn facilitate their psychological healing process. ${ }^{3}$ Members of the community can also take a more active role in the justice process, which typically involves discussion and negotiation among the parties with a stake in the dis-

* Endalew Lijalem Enyew has obtained his L.L.B. at Hawassa University, his L.L.M. at Addis Ababa University, and his M.Phil. in Peace and Conflict Transformation at the Center for Peace Studies of the University of Tromsø. He is currently a PhD fellow at the K.G. Jebsen Center for the Law of the Sea of the University of Tromsø- the Arctic University of Norway.

1 Zehr, Retributive Justice, Restorative Justice, 4 New Perspectives on Crime and Justice (1985), pp. $1-16$, at 4 . The term community in restorative justice discourse includes 'micro-community', also called 'primary stakeholders' or 'community of care', which comprises of family members, friends, and others with whom the victim and the offender have meaningful personal relationships regardless of geographical location; and 'macro-community', or 'secondary stakeholders', or 'community of place' which refers to a group of persons defined by geography or membership instead of emotional connections or personal relationships with the victim or the offender which may include neighbours and residential community. (See at note 38, McCold 2010, p. 156).

2 Christie, Conflict as Property, 17(1) British Journal of Criminology (1977), pp. 1-16, at 7.

3 Zehr, Changing Lenses: A New Focus for Crime and Justice, $3^{\text {rd }}$ ed. (Herald Press 2005), p. 191.

This is an Open-access article distributed under the terms of the Creative Commons Attribution 3.0 Unported License (http://creativecommons.org/licenses/ by/3.0/), permitting all use, distribution, and reproduction in any medium, provided the original work is properly cited. 
pute. ${ }^{4}$ In a collaborative discussion, the parties are given an opportunity to express their feelings, present their side of the story, and reach to a consensus about the damage the offense has caused, the offender's responsibility, and what should be done to restore the previous peaceful relationships. ${ }^{5}$

Contrary to the above values of restorative justice, the Ethiopian criminal justice system, as it appears through the current formal legal framework and the criminal code in particular, views crime primarily as a violation of the state's criminal laws, rather than as a violation of relationships between the parties and the community at large. ${ }^{6}$ It is the state's sole responsibility to respond to it, relying mainly on punishment. The Federal Democratic Republic of Ethiopia's (FDRE) Criminal Code, article 1, paragraph 2 states that:

the code aims at the prevention of crimes by giving due notice of the crimes and penalties prescribed by law and should this be ineffective by providing for the punishment of criminals in order to deter them from committing another crime and make them a lesson to others, or by providing for their reform and measures to prevent the commission of further crimes.

Thus, the current criminal law of Ethiopia emphasises punishment as the main instrument to prevent the commission of crimes. However, the mere imposition of a punishment cannot be seen as constructive: perhaps it sometimes encourages criminal behaviour, and it does not bring the offender to account. In addition, the criminal justice system marginalises victims of crime and makes them 'mere footnotes of the process,' little is done to help the victim restore and repair the damage caused to him by the crime, and the community is excluded from participation and ownership over criminal matters.

Nonetheless, some efforts have recently come underway to improve the current criminal justice system by introducing a new criminal justice policy and drafting a new code of criminal procedure. These proposed documents foresee a more promising environment for the implementation of restorative justice practices for certain types of crimes, as a complement to the criminal justice system.

Based on an analysis of pertinent legislations, relevant literature on restorative justice, and interviews, this article explores the limited room available for restorative justice within the legal framework of Ethiopia's current criminal justice system. It examines the prospect for restorative justice by analysing the latest proposals, and highlights further challenges that must be addressed. The article begins in section two with a discussion of

$4 \quad$ Daly, Revisiting the Relationship between Retributive and Restorative Justice, Paper presented at Restorative Justice and Civil Society Conference (Australian National University 1999), p. 5.

$5 \quad$ Wenzel et al., Retributive and Restorative Justice, 32 Law Hum. Behav. (2008), pp. 375-389, at 376.

6 Criminal Code of the Federal Democratic Republic of Ethiopia, Federal Negarit Gazeta (Proclamation No.414/2004), Art. 23.

$7 \quad$ See Zehr 1985, p 1. 
the meaning, rationale and key principles of restorative justice. The third section provides an overview of the Ethiopian criminal justice system through the lens of the formal legal framework. This is followed in section four by a study of the place for restorative justice within the existing Ethiopian criminal justice system. Section five discusses some of the recent developments intended to include values and principles of restorative justice in the Ethiopian criminal justice system. Section six highlights further tasks that must be undertaken to properly implement restorative justice practices in Ethiopia; and a conclusion is drawn in section seven.

\section{Restorative justice: its meaning, rationale, and key principles}

\subsection{Defining restorative justice}

There is no consistent and universally accepted definition of restorative justice, partly due to the expanding discussion of the concept. Some restorative justice scholars even question the need to define restorative justice arguing that a definition might limit the concept to a particular context, or limit its responsiveness to local needs, and they prefer to leave it undefined to give space to flourish. ${ }^{8}$ However, in order to avoid the concept being misused for practices that are not restorative, different working definition $s^{9}$ are provided.

Tony Marshal, for instance, defines restorative justice as 'a process whereby all parties with a stake in a specific offence collectively resolve how to deal with the aftermath of the offence and its implications for the future. ${ }^{10}$ Zehr has refined Marshal's definition as:

Restorative justice is a process to involve, to the extent possible, those who have a stake in a specific offense to collectively identify and address harms, needs and obligations in order to heal and put things as right as possible. ${ }^{11}$

The most comprehensive working definition of restorative justice was provided by Cormier:

Restorative justice is an approach to justice that focuses on repairing the harm caused by crime while holding the offender responsible for his or her actions, by providing an opportunity for the parties directly affected by a crime - victim(s), offender and community - to

$8 \quad$ Sharpe, How Large Should the Restorative Justice "Tent" be?, in Critical Issues in Restorative Justice, eds. Zehr and Toews (Lynne Rienner Publishers 2010), pp. 17-31, at 18.

9 While some scholars describe restorative justice in terms of its core values and principles, some others have resorted to defining it negatively in terms of what restorative justice is not by comparing it with criminal justice system (see note 135, Van Ness 2005, p. 4).

10 Marshal, Restorative Justice: an Overview, Report by the Home Office Research Development and Statistics Directorate (United Kingdom, 1999), p. 5.

11 Zehr, The Little Book of Restorative Justice (Good Books 2002), p. 40. 
identify and address their needs in the aftermath of a crime, and seek a resolution that affords healing, reparation and reintegration, and prevents future harm. ${ }^{12}$

All of the above working definitions have in common the notion of participating of all those having a stake in a particular crime in order to address the harm, to restore the parties into their previous peaceful relationships, to reintegrate the offender back into the community, and to prevent future crimes, all of which are expressions of restorative justice values.

\subsection{The rationale for restorative justice}

Restorative justice views crime and the responses thereto differently than the typical formal criminal justice system. It is a way of looking at crime and justice through a different lens, a 'restorative lens', as an alternative and complementarily to the traditional criminal justice system, as the latter fails to meet the needs of the victims, offenders, and the community at large. ${ }^{13}$ Nils Christie has observed that the traditional formal criminal justice system, with professional lawyers and judges playing a dominant role, tends to exclude the 'legitimate owners of the conflict' namely the victim, the offender, their families and the community members, from playing any meaningful role in the process. ${ }^{14}$

The criminal justice system marginalises the victims of a crime, forcing them to the periphery. ${ }^{15}$ Zehr states:

If victims are involved in their case at all, it will likely be as witnesses; if the state does not need them as witnesses, they will not be part of their own case. The offender has taken power from them and now, instead of returning power to them, the criminal law system also denies them power. ${ }^{16}$

That is, the victim of a crime is 'a sort of double loser, firstly, vis-à-vis the offender, and secondly being denied rights to full participation in the criminal justice ritual. ${ }^{17}$ Additionally, whatever the outcome of the case in the criminal courts, the victim does not receive any significant benefit to mitigate their suffering and nothing helps them to

12 Cormier, Restorative Justice: Directions and Principles-Developments in Canada, available at http://www.internetjournalofcriminology.com/Gavrielides_Restorative_Practices_IJC_ November_2011.pdf (Checked 14 Dec. 2014).

13 See Zehr 2005, p. 184.

14 See Christie 1977, at 4.

15 See Zehr 1985, at 1.

16 Ibid.

$17 \quad$ See Christie 1977, p. 3. 
restore and repair the damage caused to them by the crime. This is because there is little or no possibility to compensate the victims of the crime. ${ }^{18}$

The traditional criminal justice system cannot be seen to function properly for offenders either, as it does not encourage them to be accountable, to understand the consequences of their wrongful action, and to assume responsibility to right the wrong. ${ }^{19}$ The criminal justice system typically emphasises the determination of guilt through an adversarial contest between legal professionals representing the state and the offender, and punishing the latter for his wrongdoing when a conviction is pronounced. ${ }^{20}$ Punishment, in many criminal systems including Ethiopia's, is mainly imposed with the aim to incapacitate the offender both as retribution for the current crime and as a deterrent to possible future crimes. However, this does not mean that punishment has no place in restorative justice. Despite critics that RJ is a 'soft option' punishment, while seen in a different way, is still a part of restorative justice practices. Restorative justice processes aim at obtaining recognition of guilt from the offender, who is to be shamed by his community of care, to show remorse and make an apology, and to assume commitments to repair the harm in order to concretise the apology. ${ }^{21}$ According to Duff, these acts are 'punitive processes which constitute a punishment to the offender'.22 In other words, these are 'restorative punishments' ${ }^{23}$ which are meaningful and imposed with the purpose of achieving restoration and healing. ${ }^{24}$ Moreover, unlike criminal punishments which make the offender a passive receiver of a unilateral sanction imposed by the judge, 'restorative punishments' are 'communicative' 25 in the sense that the offender is a participant in the determination of his own punishment. ${ }^{26}$ In contrast, punishments under the conventional criminal justice system are neither 'restorative' nor 'communicative', and fail to bring the offender a feeling of responsibility, to sincerely accept his wrong, and be determined to undo it.

18 This is particularly true in the Ethiopian criminal justice system where the state court simply puts emphasis on punishment of the offender either by death, imprisonment, by fine or other forms of monetary punishments, which goes to the public purse and not to the victim, depending on the gravity of the crime.

19 See Zehr 1985, p. 2.

$20 \quad$ Ibid., p. 1.

21 Duff, Restorative Punishment and Punitive Restoration, in Restorative Justice and the Law, ed. Walgrave (Willam Publishing 2002) pp. 82-100, at 94.

$22 \quad$ Ibid., at 96.

$23 \quad$ See Zehr 2005, p. 210.

$24 \quad$ Ibid., p. 210; Duff 2002, p. 82.

25 Duff, Alternative to Punishment or Alternative Punishments?. In Retributivism and Its Critics, ed. Cragg (Franz Steiner Verlag 1992) pp. 43-68, at 51.

$26 \quad$ Ibid., p. 51. 
The conventional criminal justice system also assumes a monopoly over the justice system and excludes the wider community from participation by professing that the public is represented by a public prosecutor. It ignores the fact that the family members of the victim and the offender, and other community members, are all secondary victims who, directly or indirectly, have a stake in the crime. ${ }^{27}$

In response to such limitations of the conventional criminal justice system and with a view to rectify them, restorative justice is advocated as an alternative way of reflecting crime and justice. In other words, the rationale for the emergence and advocacy of restorative justice is to complement, but by no means to entirely substitute, the traditional criminal justice system, so as to rectify its limitations.

\subsection{The key principles of restorative justice}

The foundational premise of restorative justice is that it views criminal conflict as a violation of a relationship among victims, offenders, and community instead of portraying the state as the sole victim, and the 'property' of those stakeholders. ${ }^{28}$ Christie argues that the conflict should be restored to its 'legitimate owners,' who should be involved in determining the harm and repairing it. ${ }^{29}$ In line with such fundamental premises, restorative justice is guided by some key principles, sometimes also called 'values.' ${ }^{30}$

The first principle of restorative justice is that it emphasises making amends or reparations to the harm resulting from the crime by imposing obligations on the offender and the community. ${ }^{31}$ It focuses on the offender's responsibility to understand the consequences of his wrongful act and to assume commitments to make amends for it. Making amends may take the form of concrete restitution in which the offender returns the property of the victim or financial payments, or the performance of community service so as to compensate the primary victim and the community at large. ${ }^{32}$ It may also be symbolic, if the offender makes an apology acknowledging the wrongful act, and shows sincere remorse. ${ }^{33}$ In this regard, restorative justice also imposes obligations on the community

27 McCold, Restorative justice: The role of the community, paper presented to the academy of criminal justice sciences annual conference (Boston 1995), p. 2.

$28 \quad$ See Christie 1977, p. 7

$29 \quad$ Ibid.

30 The terms 'values' and 'principles' are mostly used interchangeably by many authors of restorative justice, though some other scholars distinguish values from principles (see for example Zehr 2002, p. 38).

31 See Zehr 2002, p. 33.

32 Van Ness and Strong, Restoring Justice: An Introduction to Restorative Justice, $4^{\text {th }}$ ed. (Anderson Publishing 2010), p. 87.

33 Schmid, Restorative Justice: a New Paradigm for Criminal Justice Policy, 134 VUWLR. (2002), pp. 91-133, at 96. 
to extend support and encouragement to the offender so as to enable him to carry out his obligation to make amends. ${ }^{34}$

Secondly, restorative justice involves the legitimate stakeholders of the crime in the process. Howard Zehr calls this principle an 'engagement' whereby the stakeholders of the crime are given significant roles in the justice process. ${ }^{35}$ Van Ness and Strong, on the other hand, uses the terms 'inclusion' and 'encounter' as separate principles of restorative justice instead of the general term 'engagement' used by Zehr. Inclusion refers to the opportunity for direct and full involvement of stakeholders in the process and in the determination of the final outcome. ${ }^{36}$ Encounter, on the other hand, highlights the fact that victims are given a chance to physically meet the offender in a safe environment to discuss the crime, harms and the appropriate responses to it. ${ }^{37}$ The engagement of stakeholders in the process is a manifestation of their empowerment. Restorative justice processes aim to empower the victims by giving them a forum to verbalise their feelings, to confront, ask questions to and receive answers directly from the offender about the crime, and by giving them a chance to suggest ways of resolving the crime and addressing the harm. As McCold stated, it is plausible that 'what brings the most healing and the best way for individuals affected by a crime to reliably meet their needs is the very act of participating in the process and deciding what will happen. ${ }^{38}$ Similarly, restorative justice may empower the offender by giving them the chance to be involved in the process, in the discussion with the victim, and other members of the community, and in the determination of their own punishment. Viewing punishment in a 'communicative' perspective, it should be a two-way communication, not a one-way directive aimed at a passive offender. ${ }^{39}$ Thus, restorative justice processes aim to empower the offender instead of making them a passive receiver of the unilateral decision imposed by the court. In addition, restorative justice practices empower the community as it enables it to identify and address the root cause of the crime, so as to prevent the commission of further crimes. ${ }^{40}$ Therefore, the principle of engagement, in addition to giving victims and offenders a bigger role in the process, recognises the community as a victim of the crime and its role in the justice system.

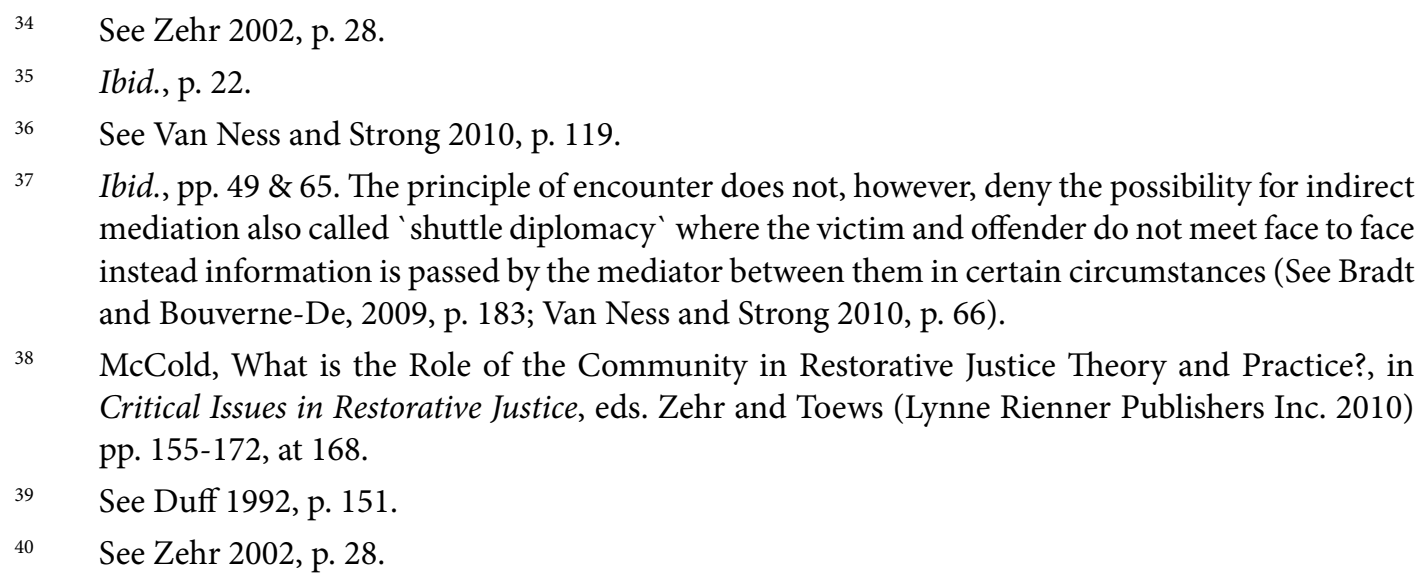


Thirdly, restorative justice encourages the voluntary participation of the parties concerned. According to this principle, restorative justice requires the participation of the parties to be based on their own free will, and without any external coercion. ${ }^{41}$ The voluntary participation of the victim and/or of the offender also implies that they are free to withdraw their consent at any time during the process. ${ }^{42}$ This freedom is an important feature of restorative justice.

The fourth principle of restorative justice is that it advocates a collaborative sanctioning process in dealing with the crime. ${ }^{43}$ Unlike the 'battle model' of the adversarial process which is guided by strict legal procedures and formalities, and where the outcome is merely decided by a judge or juries, as the case may be, restorative justice emphasises processes that are flexible, collaborative and inclusive, and outcomes that are mutually agreed upon, rather than externally imposed. This collaborative process may help the parties to discover the whole truth about the wrong done, including its causes, the harm suffered, community values, and their future relationships. ${ }^{44}$ Restorative justice, in a deliberative and collaborative interaction, gives a chance to the parties to air their feelings, present their version of the story, and through the help of their community, to arrive at an agreement about the harm the crime has caused, the offender's responsibility, and what should be done for justice to be restored. ${ }^{45}$

Fifthly and finally, restorative justice aims to restore and reintegrate the parties into the community by focusing on the crime's stakeholders and addressing the harm they suffered ${ }^{46}$ Since restorative justice views crime as a harm done to parties and communities, it tries to identify their injuries and needs and address them positively. ${ }^{47}$ It addresses the physical harm and material loss the primary victims may have sustained. Similarly, restorative justice also focuses on the injuries suffered by offenders which either could be contributing injuries, those that 'existed prior to the crime and provoked the wrongdoing' such as prior victimisation; ${ }^{48}$ or resulting injuries which are 'caused by the crime itself or its aftermath. ${ }^{39}$ The resulting injuries especially may be caused by the 'criminal justice system's response as it stigmatises and alienates the offender from the community

41 Luna, Punishment Theory, Holism, and the Procedural Conception of Restorative Justice, 205(1) Utha Law Review. (2003), pp. 205-302, at 291.

42 UN Basic Principles on the Use of Restorative Justice Programs in Criminal Matters, Economic and Social Council Resolution, E\2002\INF\2\Add.2, 2002, Article 7.

$43 \quad$ See Schmid 2002, p. 96.

44 Van Ness, Creating Restorative Systems, in Restorative Justice and the Law, ed. Walgrave (Willam Publishing 2002), pp. 130-149, at 134-135.

$45 \quad$ See Zehr 2005, p. 191.

$46 \quad$ Ibid., p. 128.

$47 \quad$ Ibid.

$48 \quad$ See Van Ness and Strong 2010, p. 45

49 Ibid. 
and family relationships.' ${ }^{50}$ Thus, restorative justice, through family care and community support, aims also at healing the injuries suffered by offenders, thereby facilitating their reintegration into the community. In other words, restorative justice contributes to a process of 're-integrative shaming. ${ }^{51}$ Unlike disintegrative shaming, re-integrative shaming involves a disapproval of the community of the wrong done while being accompanied by acts to 're-integrate the offender back into the community of law-abiding citizens through words or gestures of forgiveness or ceremonies to decertify the offender as deviant. ${ }^{32}$ It is shaming with respect in the sense that the shaming relates to the offender's wrongful act and not to his real personality. The presence and support of those who care most for both the victim and the offender, and their discussion of the consequences of the wrongdoing, makes it difficult to avoid shame in restorative justice processes..$^{53}$ Yet, their support and care after the shaming process help to reintegrate the offender into his community.

The above guiding principles of restorative justice illustrate the emphasis that restorative justice bestows on the role of the victim, the offender, and community members, through their active participation in the justice process, making offenders directly accountable to the victim and community they have harmed, restoring the material and moral losses of victims, and providing opportunities for discussion and negotiation which may lead to sustainable peace for all.

\section{The Ethiopian criminal justice system and its mode of operation}

\subsection{The modus operandi of the Ethiopian criminal justice system at a glance}

Ethiopian criminal law has the objective of 'ensuring order, peace and the security of the state, its peoples, and inhabitants for the public good. ${ }^{54}$ From the perspective of Ethiopian criminal justice, crime is viewed primarily as a violation of the state's criminal laws rather than as the violation of the relationship between individuals and the community at large. Article 23(1) of the Ethiopian criminal code defines crime as 'an act which is prohibited and made punishable by law. In this Code, an act consists of the commission of what is prohibited or the omission of what is prescribed by law..$^{55}$ Ethiopian criminal law, therefore, views crime as a violation of criminal law, which is enacted to protect the public interest, in the form of either act or omission.

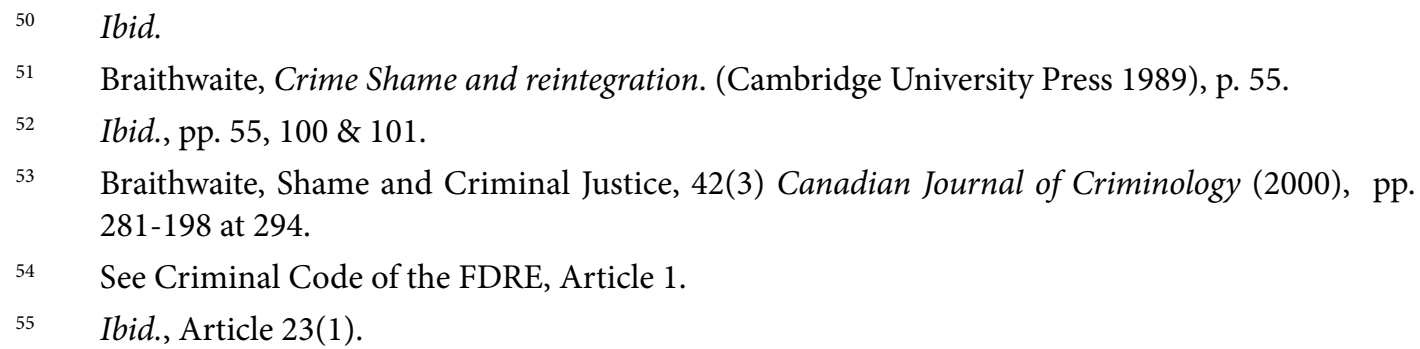


In legal terms, it is the state's responsibility to respond to crimes, acting on behalf of the public at large. In an aim to respond to occurring crimes and for the prevention of possible future crimes, the state mainly relies on the punishment of offenders. ${ }^{56}$ In other words, Ethiopian criminal law emphasises the punishment of guilty offenders as an instrument to prevent the commission of crimes after due notice has been given ${ }^{57}$ of acts which are considered crimes, together with their correlated punishments, with the aim of deterring individuals from violating criminal law. However, in order to establish guilt and to assess the ultimate punishment to be imposed on the offender, the Ethiopian criminal justice system uses the following process.

\subsubsection{Setting justice in motion}

The first stage in Ethiopian criminal justice is for the system to be set in motion by the provision of information in the form of either an accusation or a complaint ${ }^{58}$ to the police or public prosecutor. The accusation or complaint can also be delivered directly to the court if the accused is a young person, ${ }^{59}$ except for flagrant offences. ${ }^{60}$ Although any person who has witnessed the commission of a crime has the right and sometimes the duty to report it, ${ }^{61}$ it is the victim of the crime who mostly reports to the police that a crime is committed against him. In other words, the victim is most of the time the first person to report to the police and to provide a detailed statement about the crime, mainly because he is presumed to know the details of the offence more than anyone else.

\subsubsection{Police investigation}

After receiving an accusation or compliant with details of the alleged crime, the investigating police officer starts the investigation in order to establish whether the alleged

$56 \quad$ Ibid., preamble, para. 7.

$57 \quad$ Notification is achieved mainly through the publication of laws in the legal bulletin, known as Negarit gazette. The principle of ignorantia juris non excusat applies.

58 Code of Criminal Procedure of the Empire of Ethiopia, Negarit Gazeta (Extraordinary Issue No. 1\1961), Articles $11 \& 13$. An accusation or complaint is a formal statement, which should be couched in writing, made by a complainant to the police or public prosecutor with a view for proceedings to be instituted. Yet, though both the terms 'accusation' and 'complaint' refer to information communicated to the police or public prosecutor, the term 'complaint' is specifically used for crimes punishable only upon the request of the private victim (cf. Code of Criminal Procedure, Articles 11, 13, 16 \& 17).

$59 \quad$ Ibid., Articles 16(1) \& 172(1).

60 In the case of flagrant offences, the criminal justice system starts operating without accusation or compliant being lodged, except for crimes punishable only upon private compliant.

${ }_{61}$ Ibid., Article 11. The Ethiopian Criminal Code imposes a duty to report the commission of a crime for some serious crimes, such as crimes against the constitutional order, in which case failure to report brings criminal liability. 
crime has indeed been committed, and whether it was committed by the suspected person. In cases of crimes committed by young persons, however, the police cannot start the investigation before receiving instructions from the court. The court having jurisdiction for that specific case may give instructions to the police regarding the manner in which the investigation should be conducted, or it may directly instruct the public prosecutor to bring charges without requiring the police to conduct further investigations if the accusation of the young person is related to a crime punishable with rigorous imprisonment exceeding ten years or with death. ${ }^{62}$

The police investigation process involves the arrest and interrogation of the suspect, search-and-seizures for the purpose of obtaining any objects that may be used as an evidence for the case, as well as the calling of witnesses.

An arrest of the suspected person is made to ensure his presence before the police officer or the court. The arrest of a suspect can be effectuated immediately without warrant in case of flagrant offences, ${ }^{63}$ or with a summons, ${ }^{64}$ or with a warrant if the suspected person fails to appear before the investigating police officer disregarding the summons issued to him. ${ }^{65}$ Once the suspect is in attendance, the investigating police officer proceeds to interrogation with a view to eliciting relevant information about the crime of which the person is suspected. ${ }^{66}$ As the case may be, the suspect is 'asked to answer the accusation or compliant made against him' without, however, being intimidated or coerced ${ }^{67}$

To increase the chance of obtaining relevant evidence about the alleged crime, the police may also make searches and seizures. The search may be conducted on the person or body of the arrested person 'if it is reasonably suspected that he has about his person any articles which may be material as evidence in respect of the offence with which he is accused or is suspected to have committed. ${ }^{6}$ Search and seizure may also be undertaken on the suspect's premises, be they residential or business-related, so as to obtain items which could be presented in court as an exhibit. ${ }^{69}$

Moreover, the police may 'summon and examine any person likely to give information on any matter relating to the offence or the offender'70 so as to facilitate the investigation

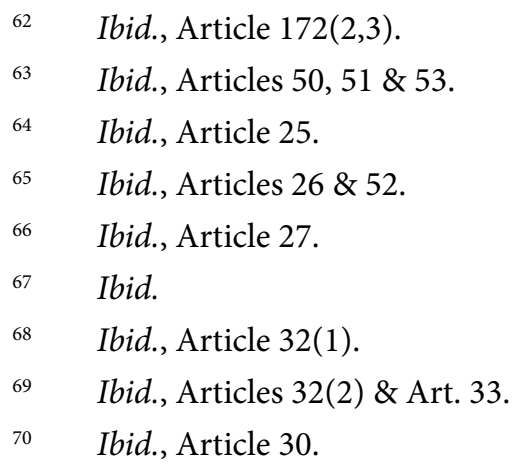


process. These persons may later appear as witnesses of the public prosecutor during court proceedings. The victim of the crime is often called to appear as a witness. ${ }^{71}$

Finally, the investigating police officer will submit a report on the investigation's results to the public prosecutor with a recommendation on the institution of court proceedings. ${ }^{72}$

The public prosecutor will bring charges unless the case is declined based on the grounds provided under Articles 39 and 42 of the code of criminal procedure. Under Article 39, these grounds are: if the accused has died, or is an infant, or cannot be prosecuted due to immunity. Article 42 states that the public prosecutor may decline the case if he believes that the evidence is not sufficient to justify conviction; if it is not possible to find the accused and the case cannot be tried ex parte; if the statute of limitation has lapsed or the offence is subject to pardon or amnesty; or if the public prosecutor is instructed by the Minister of Justice not to institute a proceeding on grounds of public interest. However, the law is silent on the fate of the case after the public prosecutor's refusal to bring charges.

What is to be done with cases where the public prosecutor has declined to institute proceedings? It would be one possibility to divert such cases to restorative justice options in order to reconcile the parties and/or their respective families, and to restore their previous peaceful relationships. This is because, as can be understood from the above-mentioned requirements prescribed by law, that the case is declined by the public prosecutor does not necessarily imply that the crime was not committed, nor does it bring the matter to an end. It simply means that the legal requirements to institute proceedings before a criminal court are not fulfilled.

A person well versed in criminal law may argue that the accused should be presumed innocent, and should not be required to go through any restorative justice process if there exists grounds for the prosecutor do decline bringing charges. Nonetheless, this approach would not bring a lasting peace given the practice of vengeance which is culturally accepted in many parts of Ethiopia. The victim's grievances would not be addressed and consequently he or his relatives may keep a grudge and may resort to vengeance unless reconciliation is reached through restorative justice options.

On the other hand, if there are no grounds impeding prosecution, the public prosecutor will institute proceedings by preparing and lodging charges to the appropriate court, and the actual trial will start.

71 Interview with Mr. Ashenafi Molla, Federal Public Prosecutor, Ministry of Justice, Gulele Subcity Justice Office, July 2012.

72 See Criminal Procedure Code, Article 37. 


\subsubsection{Trial (Hearing)}

Trial is the core of the criminal justice system: it is there that adversarial litigation between the public prosecutor, representing the state, and the accused, or his representative, is conducted.

The appearance of both parties before a court is a pre-requisite for the proceedings to start. To that end, immediately after the public prosecutor files the charge to the appropriate court, the latter fixes the date of trial and summons both the public prosecutor and the accused to appear before the court at the appointed date and time. ${ }^{73}$ If the accused person is in custody, the court sends a letter to the prison administration prior to the appointed date so that the accused may be brought to court. If the accused is released on bail or not arrested and fails to appear before the court disregarding the court summons, the court may issue a warrant of arrest, or bench warrant, so that the accused be brought in on the appointed day. ${ }^{74}$

Upon the start of proceedings, the accused shall appear personally ${ }^{75}$ before the court, 'adequately guarded,' and in certain circumstances 'chained,' if it is believed that he is dangerous or may become violent, or may try to escape. ${ }^{76}$

Moreover, the accused is separately placed in a dock after his identity is verified. ${ }^{77}$ Once the appearance of the parties before the court is secured, the charge is read out and explained to the accused who is asked whether he shall plead guilty or not guilty. ${ }^{78}$ If the accused pleads guilty, he may be convicted immediately, or the court may demand that the prosecutor corroborate the plea with evidence if it is not satisfied with the plea of the accused..$^{79}$ If the accused pleads not guilty, or pleads guilty but the court orders the plea to be corroborated with evidence, the actual adversarial litigation starts, in the sense that both parties then present their evidences to convince the court.

$73 \quad$ Ibid., Article 123.

$74 \quad$ Ibid., Article 125.

75 Unlike for civil proceedings, the personal appearance of the accused is mandatory in criminal proceedings even if he is represented by a defence attorney of his own choosing, or provided at the expense of the state if they do not have sufficient means to pay for it and miscarriage of justice would result.

$76 \quad$ Ibid., Article 127 (1, 2).

77 Ibid., Article 127(3).

78 Ibid., Articles $129 \& 132$. If the accused denies the charge or admits the charge with reservations irrespective of the degree of reservation, or if the accused remains silent, the plea of not guilty shall be recorded (Article 133 of the Criminal Procedure Code). On the other hand, the plea of guilty shall be recorded if and only if the accused admits the charge without reservation either by stating the offence by its names or by admitting every ingredient of the offence charged (Article 134(1) of the Criminal Procedure Code).

Ibid., Article 134(1, 2). 
The public prosecutor takes the lead, by presenting any material evidence and calling witnesses. The witnesses pass through different phases of examinations such as examination-in-chief, cross-examination, and re-examination. As highlighted above, a crime's victim is in practice a primary witness for the public prosecutor, even though the law does not require that the victim testify. However, the public prosecutor may not call the victim as a witness if he believes that another person can prove the accused's guilt better than the victim. This implies that the victim of the crime is not in the centre of the Ethiopian criminal justice system as discussed below in more depth.

After the public prosecutor has presented his evidence and all the witness examinations are concluded, the accused is also given a chance to defend his case, unless the court reaches a verdict of acquittal based solely on the evidence presented by the public prosecutor. $^{80}$ The accused or his representative, then presents his defence, introduces material evidence and calls witnesses for the defence. ${ }^{81}$ As for the prosecution, all witnesses must pass through the different examination stages. The accused contradicts the facts as professed by the prosecution. However, the defence is not required to prove the case beyond reasonable doubt; instead it is only required to prove that there remains a level of doubt over the veracity of the prosecution's accusations.

Finally, after the prosecution and the defence have presented their evidence, the court will render judgment and pronounce a sentence weighing the evidence in light of the law.

\subsubsection{Judgment and Sentencing}

Evaluating the evidence submitted by both parties, the judge(s) rules whether the accused is guilty or not guilty. To determine the guilt of the accused, the court examines whether the defence has successfully cast a reasonable doubt on the prosecution's case based on the oral arguments and evidence presented. If a doubt as to the accused's guilt persists in the mind of the judge(s), the court will acquit the accused. In other words, it is only when the accused has failed to cast such a reasonable doubt that the court may convict the accused for the crime charged.

If the accused is found to be not guilty, this must be clearly stated in the judgement, which also must order the accused's acquittal, as well as his release if he is in custody. ${ }^{82} \mathrm{On}$

80 Ibid., Article 141. The court has a discretionary power to acquit the accused after merely evaluating the evidence presented by prosecution and without requiring the accused to defend himself. This is relevant when the court is not convinced by the evidence for the prosecution. If the public prosecutor cannot prove beyond reasonable doubt that the accused has committed the crime in the first place, requiring the accused to defend his case is aimless. As a result, the court may acquit the accused and order him released without demanding him to present his defence.

$81 \quad$ Ibid., Article 142.

82 See Code of Criminal Procedure, Article 149(2). 
the other hand, if the accused is found to be guilty, the court, after asking both the public prosecutor and the accused party for their opinion on sentencing in terms of aggravation or mitigation, ${ }^{83}$ imposes the sentence or punishment on the offender. ${ }^{84}$

In such a situation, therefore, the victim of the crime is not given a chance to address the judge about the impact of the crime on him, to seek compensation, or to be involved in the determination of the appropriate punishment rendered onto the offender. The accused also has no role in the determination of his punishment beyond expressing his opinion on sentencing based on mitigating circumstances. The judge(s) rules on the appropriate sentence, leaving the accused as a passive receiver of its unilateral decision, and orders the appropriate authorities to execute it subject to the right of the unsatisfied party to lodge an appeal to a higher court.

\subsection{Types of punishment}

The punishments imposed by the court may vary depending on the nature and gravity of the crime, the circumstances of its commission, as well as the character of the offender. ${ }^{85}$ In general terms the criminal code provides two broad categories of punishments: principal punishments and secondary punishments, as discussed below.

Principal punishments are those punishments primarily and independently imposed on the offender for the crime he has committed. These are further classified into three categories: pecuniary penalties, compulsory labour, and penalties entailing the convict's loss of liberty or life, consisting of imprisonment and the death penalty respectively.

83 Ibid., Article 149 (3). Aggravating and mitigating circumstances are factors that must be considered before passing the sentence and are used to increase or decrease the punishment respectively. Some of the aggravating circumstances provided under the Ethiopian criminal law include: treachery, base motive, deliberate intent to do wrong, cruelty, abuse of power, antecedents or past criminal record of the accused, time and circumstances of the commission of the crime, criminal agreement, commission of a crime against victims deserving special protection, concurrence crimes, and recidivism (See Articles 60, 67, 84, 85, 183, 184 of the Criminal Code). Similarly, the mitigating or extenuating circumstances include: the age, level of education, character, health, economic position, motive of the accused, and the existence of provocative situation (see Article 82, 83, 179, 180 of the Criminal Code).

84 Ibid., Article 149 (5).

85 See Article 88(2) of the Criminal Code. 
Pecuniary penalties, also called monetary penalties, are those penalties that affect the criminal's property, and include: fines, confiscation, sequestration, and forfeiture. ${ }^{86} \mathrm{~A}$ fine is the most commonly used type of monetary punishment and is calculated taking consideration to 'the degree of guilt, the financial condition, the means, the family responsibilities, the occupation and earnings therefrom, the age and health of the offender. ${ }^{87}$ The amount of money collected from fines as well as any property confiscated or forfeited goes to the public purse and not to the victim of the crime. If the victim of the crime has a right to restitution or compensation for the damage caused to him, it must as a rule be claimed through a separate civil action, barring some exceptions discussed below where a claim for compensation can be made as part of the criminal proceedings.

Compulsory labour is another type of principal punishment which may be imposed on the offender if 'the crime is of minor importance and is punishable with simple imprisonment for a period not exceeding six months, and the criminal is healthy and not a danger to society. ${ }^{88}$ It will be imposed as a substitute for a fine if the offender is unable to pay it, and a substitute for simple imprisonment if the court believes that such sentence is more conducive to the offender's reform than imprisonment. ${ }^{89}$ In such a case, the court will determine the duration and the manner of execution of compulsory labour, and the offender is required to serve the compulsory labour sentence in his normal working place or in a public establishment or for public works subject to supervision, with or without restriction of his personal liberty, and an amount not exceeding one third of the wages or profit is paid to the state. ${ }^{90}$ The important point to note here is that compulsory labour used as a form of punishment under the Ethiopian criminal code is different from the community service ideals of restorative justice. This is because it is not a voluntary ser-

According to Ethiopian criminal law, confiscation is recognised as a type of pecuniary penalty which involves the taking of 'any property which the criminal has acquired, directly or indirectly, by the commission of a crime for which he is convicted.' It may also extend to any property lawfully acquired by the offender if there is an express provision to that effect in the criminal code (see Article 98 of the Criminal Code). Sequestration is another type of pecuniary penalty which may be ordered by the court 'when the criminal has been convicted and sentenced in his absence for conspiring or engaging in hostile acts against the constitutional order or the internal or external security of the state.' (See Article 99 of the Criminal Code). Finally, forfeiture involves the seizure of any material benefits given or intended to be given to a criminal as payment or reward for committing a crime, or the fruits of a crime (See Article 100 of the Criminal Code).

$87 \quad$ Ibid., Article 90(2).

88 Ibid., Article 103(1). Compulsory labour is prohibited, in principle, under the Ethiopian Constitution. However, Article 18 (4) of the Constitution recognises compulsory labour exceptionally for 'any work or service normally required of a person who is under detention in consequence of a lawful order, or of a person during conditional release from such detention.' Thus, the inclusion of compulsory labour as a form of punishment under the criminal code falls under these exceptional grounds.

89 Ibid., Articles 96, 107.

90 Ibid., Article 103 (2). 
vice undertaken to compensate the community, but is imposed. Community service in a RJ perspective, on the other hand, is a voluntary service undertaken by the offender after sincerely recognising and acknowledging the consequences of his wrongdoing, as an outcome of restorative justice processes. However, both community service and compulsory labour are similar in that both are alternatives to custodial punishments.

The third category of principal punishments provided under the criminal code are penalties entailing loss of liberty or life: imprisonment and the death penalty respectively. Imprisonment can be 'simple imprisonment' extending from ten days to three years imposed in relation to 'crimes of not very serious nature and committed by persons who are not a serious danger to society. ${ }^{11}$ It can also be 'rigorous imprisonment' extending from one year to twenty five years, or life imprisonment, imposed in relation to 'crimes of a very grave nature committed by criminals who are particularly dangerous to society. ${ }^{92}$ Death penalty is the most serious punishment entailing loss of life provided for under the criminal code, and is carried out after considering stringent conditions. These conditions, as provided for under Article 117 of the criminal code, include the gravity of the crime, the exceptional dangerousness of the criminal, that the criminal must have been eighteen years of age at the time of the commission of the crime, that the crime must have been completed, the absence of any extenuating circumstances, that the relevant provisions of the criminal code must expressly provide for death penalty, that the head of the state must approve it, and that it is executed after pardon or amnesty have been denied..$^{93}$

The other categories of punishments under Ethiopian criminal law are secondary punishments. These may be imposed in addition to principal punishments. Secondary punishments shall not be applied in the absence of any principal punishment or in the absence of express direction of the court to that effect, except for young offenders. ${ }^{94}$ These secondary punishments include: caution, reprimand, admonishment and apology, deprivation of rights, and dismissal from the armed forces and/or a reduction in military rank. Article 122 of the criminal code states that, for certain crimes, the Court 'may, either during the trial or in its judgment, admonish or reprimand the criminal. This particularly applies when the offender is young, in which case the court may admonish or blame not only the young offender but also the parents or other persons legally responsible for the young offender if they failed to properly carry out their duties as a parent or guardian. ${ }^{95}$

In sum, the court, after establishing the guilt of the accused, imposes the appropriate principal punishments either alone or together with secondary punishments, and orders the appropriate authorities to execute the sentence subject to the right of the parties to

\footnotetext{
$91 \quad$ Ibid., Article 106.

$92 \quad$ Ibid., Article 108.

$93 \quad$ Ibid., Article 117.

$94 \quad$ Ibid., Article 121.

95 See Code of Criminal Procedure, Article 178.
} 
lodge an appeal to a higher court. Though the Ethiopian criminal justice system also has other purposes for punishment, such as deterrence, restraint, or incapacitation, as well as rehabilitative purposes, the focus placed on principal punishments clearly shows that the emphasis is on the retributive rather than on the restorative purpose of punishment.

\section{Is there space for restorative justice in the current Ethiopian criminal justice system?}

As discussed above, the Ethiopian criminal justice system focuses on the offender's crime, and has punishment as its primary purpose. It does not encourage the offender to take responsibility to undo the wrong he has committed by performing positive actions towards the victim or the community at large. Similarly, the accused is required to personally appear before the court 'adequately guarded' or in certain circumstances 'chained' and is separately placed in a dock after his identity is verified at trial. The fact that he is adequately guarded, chained and separately placed in a dock may lead the community to see him permanently as a criminal with a reprehensible personality and may segregate him as a consequence. These practices may also increase the likelihood of subsequent objectionable behaviour by the offender, as he may feel hated and cast out by the community. ${ }^{96}$ Such perceptions from the community and attacks on the offender's self-esteem may lead him to feel revengeful and reoffend, or to withdraw himself from the community, which may eventually lead to a disconnection from his social bonds. ${ }^{97}$ These rituals, therefore, manifest the stigmatic and disintegrative nature of the Ethiopian criminal justice system. In addition, the accused is reduced to a passive participant mostly represented by his defence lawyer through the criminal justice process. He has no role in the determination of his punishment beyond expressing an opinion on the sentence's mitigation; he is a passive receiver of the unilateral decision of the judge.

Victims of the crime are not at the centre of the Ethiopian criminal justice system either. Their role is limited to providing information in the form of an accusation or complaint so as to set the justice in motion, or to be merely a witness in his own case if, at all, the public prosecutor needs him to testify. The public prosecutor may not call the victim as a witness if he finds another person who can prove the case better than the victim. Thus, it is to the discretion of the public prosecutor to either include or exclude the private victim from the proceedings. Even when the victim is called as a witness, he does not have a chance to properly encounter the accused as his communication with the ac-

96 Maxwell, and Morris, What is the Place of Shame in Restorative Justice?, in Critical Issues in Restorative Justice, eds. Zehr and Toews (Lynne Rienner Publishers 2010), pp. 133-142, at 42.

97 Scheff and Retzinger, Helen Block Lewis on Shame: Appreciation and Critic, in The Widening Scope of Shame, eds. Lansky, Melvin and Morrison (The Analytic Press 1997), pp. 139-154, at 145. 
cused is limited to answers in cross-examination. The victim is also not allowed to remain in the courtroom to hear the other testimonies in the case and to attend the rest of the trial so as to avoid that other witnesses' testimonies be copied. ${ }^{98}$ They are 'left outside the courtroom, perhaps being angry and humiliated through a cross-examination in court.9 ${ }^{99}$ Though victims of a crime have an interest in attending and observing what is happening at trial, the Ethiopian criminal justice system excludes them for the sole reason that they appear as witnesses for the prosecution.

Similarly, the victim of the crime is not given a chance to address the judge about the impact of the crime on him, on the determination of the appropriate punishment to be imposed on the offender, and his right to restitution and compensation is not adequately protected. Moreover, there is no possibility to bring the victim and the offender together so as to enable them to discuss the causes and consequences of the crime, reconcile, and thereby restore and maintain their peaceful relationships and preventing possible future crimes.

The Ethiopian criminal justice system also excludes the community from participation. If the community can be said to participate in the process, it is only in the form of providing information about the commission of the crime, i.e. in the form of an accusation or compliant so as to set the justice in motion, and by merely appearing as a witness in the criminal proceedings. Further, the current code of criminal procedure leaves no opportunity for legal practitioners, i.e. prosecutors, police and judges, to identify certain cases that may be more appropriate to divert into restorative justice processes, either prior or posterior to charges being brought. Even worse, the procedural and substantive laws of Ethiopia, including the constitution, exclude the use of out-of-court mechanisms, such as customary dispute resolution mechanisms, in criminal matters, though they are used to some extent de facto. Therefore, the notion of restorative justice is almost non-existent in the current Ethiopian criminal justice system as it appears through the formal legal framework. Nonetheless, it does not mean that the Ethiopian criminal justice system shows no elements of restorative purpose. It exhibits some elements of restoration even though the term 'restorative justice' is nowhere used explicitly in the law. These restorative elements are discussed below.

\subsection{The claim for restitution or compensation}

As shown above, the amount of money collected in the form of a fine, as well as confiscated or forfeited property, goes to the public purse and not to the victim of the crime. If the

98 Interview with Mr. Gashaw Tamire, Federal Public Prosecutor, Ministry of Justice, Nifassilk Lafto Sub-City Justice Office, July 2012. The general practice in the Ethiopian criminal justice system is that witnesses are not allowed to attend the trial so as to prevent them from adjusting their testimony to make consistent with what other witnesses have said.

$99 \quad$ See Christie 1977, at 8. 
victim has suffered a loss and must be compensated, he has to bring a separate civil suit. However, there is a limited possibility by which the victim of the crime can bring a civil suit for compensation as part of the criminal proceedings. Article 101 of the criminal code states that:

Where a crime has caused considerable damage to the injured person or to those having rights from him, the injured person or the persons having rights from him shall be entitled to claim that the criminal be ordered to make good the damage or to make restitution or to pay damages by way of compensation. To this end they may join their civil claim with the criminal suit. ${ }^{100}$

The victim or his representative should apply, at the opening of the hearing, to the court trying the case so that the civil claim and the criminal case may be joined. ${ }^{101}$ The court to which the application is made may reject the application based on different grounds stated in article 155 of the code of criminal procedure which include, among others: if the determination of compensation requires numerous witnesses in addition to those called by the prosecutor or the accused, or if the court believes that the hearing of the claim for compensation is likely to confuse, complicate or delay the hearing of the criminal case. However, the application's dismissal does not prevent the victim from instituting a separate civil suit in a civil court. ${ }^{102}$

If the court allows the two cases to be joined, however, the victim is entitled to take part in the proceedings and have, with regards to evidence, all the rights given to an ordinary party. ${ }^{103}$ This means that the victim has a right to call witnesses other than those called by the prosecutor, if he wishes, and to address the court about the amount of compensation to be awarded after the end of the defence proceedings. ${ }^{104}$ The court, after a criminal charge is settled, then rules on the amount of compensation, the necessary costs and fees to be paid by the offender, as in a civil case. ${ }^{105}$ Joining the civil and criminal cases gives a victim or his representative a role almost equivalent to that of a party, and is more efficient and cheaper for them than instituting a separate civil suit. This is because, in most cases, the facts of the case and the evidence that may be produced by the public prosecutor to prove the criminal case are the same as would be used to argue the civil claim.

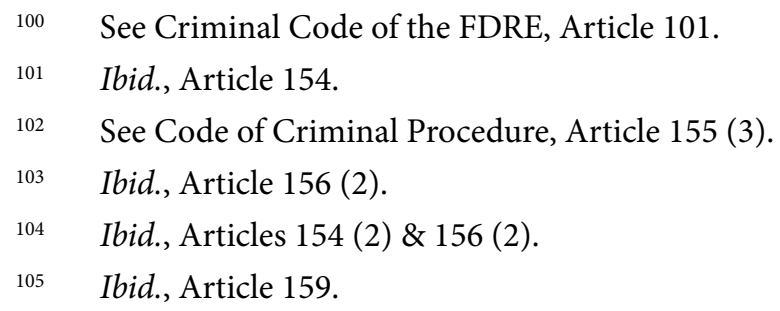


Moreover, the court is given a discretionary power to increase the likelihood that compensation is paid to the victim by ordering compensation to be paid from other sources. In this respect Article 102 (1) of the criminal code states that:

Where it appears that compensation will not be paid by the criminal or those liable on his behalf on account of the circumstances of the case or their situation, the court may order that the proceeds or part of the proceeds of the sale of the articles distrained or the sum guaranteed as surety, or part of the fine or of the yield of the conversion into work, or confiscated property, be paid to the injured party. ${ }^{106}$

According to this provision, the court is given a discretionary power to order compensation to the victim from the money guaranteed as surety, imposed as fine, part of the wage earned from a sentence of compulsory labour, or from the sale value of properties confiscated from the offender if he or those vicariously liable for him are found unable to pay the compensation.

Thus, the joining of civil and criminal cases so as to process a compensation claim is one of the restorative aspects of the Ethiopian criminal justice system. However, though this is one of the exceptions by which the Ethiopian criminal justice system allows the victims or those having rights from them to be involved in the process and to claim compensation, their participation is not automatic in the sense that they cannot participate in the process as of right. Their participation is at the discretion of the court, after the existence of considerable damage has been determined. Unlike the restorative justice ideal where the type and amount of compensation or restitution is mutually agreed upon by the parties, the Ethiopian criminal justice system gives the judge(s) ultimate discretion over the amount of compensation to be awarded based on the evidence produced. Moreover, it is not common for Ethiopian criminal courts, in practice, to entertain the issue of compensation simultaneously with criminal proceedings. This is mainly because neither are the victims well aware of this possibility of claiming compensation side by side with criminal suit, nor are the public prosecutors willing to lodge the claim for compensation as part of the criminal proceedings under the pretext of causing delay to criminal proceedings. ${ }^{107}$

\subsection{Conducting private prosecution for crimes punishable upon complaint}

Conducting private prosecution is another exception that provides for victims and other stakeholders to intervene in the Ethiopian criminal justice process. This right to initiate a private prosecution arises when the public prosecutor declines to bring charges due to insufficient evidence for a conviction, in the case of crimes that are punishable only upon

106 See Criminal Code of the FDRE, Art. 102 (1).

107 Interview with Mr. Mehammed Haji Abubeker, Federal first instance Court, Menagesha first instance Court Judge, September 2012. 
formal complaint. ${ }^{108}$ Where such a decision is made, the 'victim of the crime or his legal representative; or the husband or wife on behalf of the spouse; or the legal representative of an incapable person' may conduct a private prosecution standing as a party. ${ }^{109}$ On the day of the hearing, before reading out and explaining the charge to the accused and before asking whether he pleads guilty or not, the court attempts to reconcile the parties. ${ }^{110}$ An attempt to reconcile the parties is given priority as crimes punishable only upon private complaint imply a higher degree of private interest than public interest.

If the reconciliation is effected, it will be recorded by the court to have the effect of a judgment. ${ }^{111}$ Nevertheless, if reconciliation is impossible, the court continues to hear the case as an ordinary prosecution, and all the traditional rules of procedures (Articles 123 to 149) are followed. In such a case, any of the aforementioned private persons act as private prosecutors, and replace and assume all the responsibilities of the public prosecutor. The fact that the Ethiopian criminal justice system provides an opportunity for victims or other persons stated above to appear as a litigant in a criminal case, and the fact that the court exerts some effort to reconcile the parties indicate some restorative aspects in the Ethiopian criminal justice system.

\subsection{Probation and parole}

Though probation and parole provisions in Ethiopian criminal law mainly relate to their rehabilitation purpose, they can also be considered as other exceptional circumstances which are manifestations of their restorative character. Probation is the release of a convicted offender under the supervision of a probation officer subject to revocation upon breach of the conditions attached to his release. The Ethiopian criminal code recognises the idea of probation in which the court is given a discretionary power to order probation having regard to all the circumstances of the case and if it believes that it will promote the reform and reintegration of the criminal. ${ }^{112}$ Accordingly, the court may place a convicted criminal on probation if he has not been convicted previously, does not appear dangerous to society, and when his crime is punishable with fine, compulsory labour, or simple imprisonment of no more than three years. ${ }^{113}$ In addition, the convicted offender is required to enter into an undertaking to be of good conduct, to meet the conditions or rules of conduct attached to the probation, and to repair the damage caused by the crime or

\footnotetext{
108 See code of Criminal Procedure, Article 44(1).

109 Ibid., Article 47.

110 Interview with Mr. Gashaw Tamire.

111 Interview with Ashenafi Molla.

112 See Criminal Code of the FDRE, Article 190.

$113 \quad$ Ibid., Article 191.
} 
pay compensation to the injured person in order to be placed under probation. ${ }^{114}$ Upon granting probation, the court places the offender under the supervision of a protector, guardian, or probation officer who shall keep in touch with the offender and reports on his situation. ${ }^{115}$

Nonetheless, the court has a discretionary power to revoke the probation if the offender infringes one of the rules of conduct or conditions attached to it, or commits a new offence during the period of probation. ${ }^{116}$ Likewise, the court may disallow probation where the offender has previously undergone a sentence of rigorous imprisonment or simple imprisonment exceeding three years and is sentenced again to one of these penalties, and where the offender is sentenced to rigorous imprisonment exceeding five years for the crime for which he is now tried. ${ }^{117}$

Ethiopian criminal law also recognizes parole whereby a prisoner is conditionally released before the completion of the term of imprisonment. ${ }^{118}$ Parole may be granted by the court after receiving recommendations from the prison's administration and having regards to the behavioural reform of the criminal, provided this process helps the offender at an earlier stage to reintegrate with his family and the community. The criminal code (Article 202) lays out the requirements that must be fulfilled to allow parole, which include: the prisoner has to have served two-thirds of the custodial sentence or twenty years in case of life imprisonment; the prisoner or the management of the institution must submit respectively a petition or recommendation; the criminal should present a tangible proof of behavioural reform during the period of imprisonment; the prisoner must repair or agree with the victim or his family to repair the harm caused; and the character of the prisoner should warrant the assumption that he will be of good conduct when released. ${ }^{119}$ Similarly to probation, parole is subject to certain conditions and non-compliance with these conditions may lead to the revocation of the parole, in which case the prisoner is sent back to the prison to serve the remainder of the sentence. ${ }^{120}$

The probation and parole provisions of the Ethiopian criminal code are significant from the perspective of restorative justice. They are important to avoid the negative consequences of incarceration and to reduce the prison population, to enable the offender to remain within his community without breaking his social ties, or to re-join early with his family and the community. They are also important steps to protect the interests of victims as they put repairing the damage caused by the crime or to pay compensation

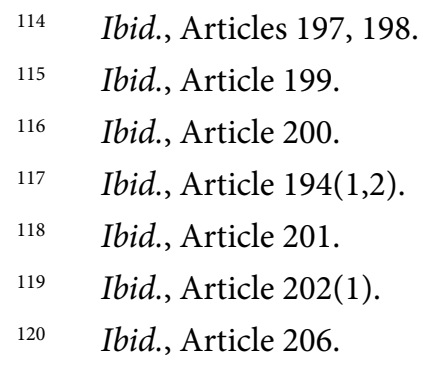


to the injured person as a requirement to be placed under probation or granted parole. Nonetheless, despite the legal provisions, there is no organ established, to date, to supervise parolees and probationers and to report to the court as to their status. ${ }^{121}$

Generally, the exceptional situations described above give some possibilities for victims of a crime to be compensated, and to participate in the criminal justice process as a litigant either by assuming a quasi-party status or by initiating private prosecution. However, restorative justice does not merely encompass the restitution and compensation of victims. It goes a level beyond by purporting to heal the injuries of stakeholders, to repair their relations, and to reintegrate the parties into their law-abiding community. Similarly, the conduct of private prosecution is allowed as notable exception only if the public prosecutor declines to prosecute and only for crimes punishable upon complaint of the private victim. Further, the criminal law provisions on probation and parole are meaningless and remain paper values in the absence of organs to supervise parolees and probationers, and to report to the court as to the status of the offender. Thus, these provisions are limited and insufficient to be considered as an embodiment of the idea of restorative justice in the Ethiopian criminal justice system. However, these provisions can serve as a basis to undertake the necessary reforms of the Ethiopian justice system so as to incorporate restorative justice values.

\section{Recent developments}

Even if the idea of restorative justice is, as shown, not yet developed in the Ethiopian criminal justice system, there have some developments in recent years. Recent documents and legislation, such as the Ministry of Justice's criminal justice policy and the new draft code of criminal procedure, provide possibilities for implementing restorative justice elements in the Ethiopian criminal justice system in the form of diversion to the out-of-court mechanisms. ${ }^{122}$

Ethiopia has introduced a new criminal justice policy with the aim of rectifying the existing problems of, and to introduce new legal thinking, practice and procedures into, the Ethiopian criminal justice system. ${ }^{123}$ Creating a procedure for the use of out-of-court

121 Interview with Mr. Meazahaimanot, Federal Assistant Attorney General, Ministry of Justice, July 2012.

122 The criminal justice policy and the draft code of criminal procedure use the general and broad term "out-of -court mechanisms" to refer to any conflict resolution mechanisms alternative to the formal criminal justice system including the modern Alternative Dispute resolution (ADR) processes, customary dispute resolution mechanisms, and other possible options.

123 Criminal Justice Policy of the Federal Democratic Republic of Ethiopia, 2011, Ministry of Justice, Addis Ababa, preamble (Translations mine). 
mechanisms so as to provide a fair and sustainable solution to crime is a part of the new legal thinking and practices given due attention under this newly enacted policy. ${ }^{124}$

The policy states that 'certain criminal cases may be referred to the out-of-court mechanism at any stage of the criminal justice process upon the request of the public prosecutor or the accused, or upon a motion of the court' so as to make the criminal justice system speedy and accessible. ${ }^{125}$ It provides general principles guiding the referral of certain criminal cases to out-of-court mechanisms taking into account: the type of crime, the character of the accused, and the circumstances of the commission of the crime, if it is believed that the interests of the public and the victims are better protected by the use of out-of-court mechanisms than the regular court system, if the accused or the offender is juvenile, female, disabled, elderly, a non-recidivist criminal, and if the offender is accused of crimes punishable with simple imprisonment and a reconciliatory agreement is reached between the accused and the victim. ${ }^{126}$

The criminal justice policy also provides specific conditions which must be fulfilled to refer the criminal case to out-of-court mechanisms which include: ${ }^{127}$ firstly, the accused person must wilfully admit to all elements of the crime and sincerely express his repentance in writing after receiving sufficient legal advice to that effect. Secondly, the accused must present an apology to the victim and express his readiness to repair or compensate the damage caused. Thirdly, the accused should be informed, in advance, that he has the right to refuse the referral of the case to out-of-court mechanism, all of which are basic elements in a restorative justice ideal.

Guided by these general principles and specific conditions, the police, prosecutors, and judges are given discretionary power to refer certain criminal cases, which are punishable by simple imprisonment or only upon private compliant, to out-of-court mechanisms. ${ }^{128}$

The new criminal justice policy, therefore, provides a general framework to implement restorative justice in the Ethiopian criminal justice system. Nevertheless, the policy is not a legislative proposal, but rather a document showing the government's policy aims and focus regarding the justice system. A separate law formulating the aspirations and principles of the policy is required for its implementation. Such a law addressing restorative justice should provide a detailed guideline on how to make referrals to out-of-court mechanisms, define precisely the nature of these mechanisms and regulate the discretionary power of the police, prosecutors, and judges while making referrals.

$\begin{array}{ll}124 & \text { Ibid., preamble. } \\ 125 & \text { Ibid., p. } 37 \\ 126 & \text { Ibid., p. } 38 \\ 127 & \text { Ibid. } \\ 128 & \text { Ibid., p. } 13\end{array}$


Likewise, a new draft code of criminal procedure was submitted for consideration a few years ago. It gives discretionary powers to public prosecutors and judges to divert certain criminal cases to out-of-court mechanisms with the aims to: utilise the justice system's limited resources for other serious crimes which cannot be referred to the outof-court mechanism; ${ }^{129}$ to easily re-integrate the offender into his community and reduce recidivism; to help the offender take responsibility and show remorse for his wrongdoings; and to protect and give voice to the victim and community at large. ${ }^{130}$ Accordingly, the public prosecutor or the judge may divert the case to out-of-court mechanisms, if they believe that resolving the criminal case through such mechanisms will serve the above objectives and result in a better resolution than the regular court system. ${ }^{131}$

According to Article 171 of the draft, the case may be diverted to out-of-court mechanisms if: the accused or the offender is juvenile, female, disabled, elderly; or the accused or the offender is under serious physical or mental illness during the commission of a crime or the hearing; and the accused or the offender is willing and ready to compensate the victim for the harm caused due to his wrong. ${ }^{132}$ Though the draft code of criminal procedure does not provide detailed and specific rules, these requirements are almost direct reflections of the criminal justice policy.

Thus, the draft code of criminal procedure is an attempt to create a conducive environment for the implementation of restorative justice ideals in the criminal justice system, which are lacking in the current code of criminal procedure. Nonetheless, its recognition of out-of-court mechanisms and of their application to criminal matters is open to critic and appeal in the absence of a clear constitutional clause which recognises the application of such mechanisms to criminal cases. This is due to the constitutional principle stated under Article 9 that any law or customary practice in contradiction with the Constitution is null and void. ${ }^{133}$ Hence, an amendment of the Constitution to include a clause expressly recognising the out-of-court mechanisms' application to criminal matters is necessary to avoid such uncertainty.

Moreover, the diversions to out-of-court mechanisms foreseen in the draft code of criminal procedure are limited only to minor crimes and crimes punishable upon private complaint. Its scope of application should be reconsidered to include some serious crimes. It may be possible to perhaps combine the restorative justice option using out-of-

129 Draft Code of Criminal Procedure of the Federal Democratic Republic of Ethiopia, 2010, Draft Legislation, Ministry of Justice, Addis Ababa (Translation mine). Article 170 (2) provides that serious crimes stated in the Ethiopian criminal code cannot be referred to the out-of-court mechanisms.

$130 \quad$ Ibid., Article 169.

$131 \quad$ Ibid., Article 170(1,2)

$132 \quad$ Ibid., Article 171

133 Constitution of the Federal Democratic Republic of Ethiopia, Art. 9. 
court mechanisms with the formal criminal justice system in certain serious crimes. The law should give due recognition to the settlement of the criminal conflict and reconciliation of the offender with the victim or his family through out-of-court mechanisms, and considering this fact, the court should be given discretion to reduce the penalty provided under the criminal code thereby giving space for both the criminal justice and restorative justice models. This modality is both backwards-looking in that the criminal is punished by reduced penalty under the criminal law for his offence; and forward-looking in the sense that the parties and their respective families are reconciled not to resort to vengeance, and give a pledge for their peaceful future relationship.

Generally, despite the aforementioned limitations, the recently prepared criminal justice policy and the draft code of criminal procedure are the biggest opportunities yet to properly incorporate restorative justice ideals into the Ethiopian criminal justice system.

\section{Further hurdles to overcome}

Despite the fact that recent developments provide opportunities which boost the prospects for the implementation of restorative justice, this process is far from being at an end. There are still countless hurdles to overcome and many infrastructures to put in place in order to materialise these opportunities into practical terms. In addition to the recent documents' shortcomings, there are other challenges which need to be addressed in order to properly implement restorative justice in Ethiopia.

Beyond the legal rules, the establishment of appropriate models or programs is required to implement the values and principles of restorative justice. Depending on the choice of the parties, the type of conflict, and available resources, different restorative justice programs have been functioning in different countries. Well-known models, which are considered to be the hallmarks of restorative justice processes, include: Victim-Offender Mediation (VOM), Family Group Conferencing (FGC), and Sentencing Circles (SC).

In a similar vein, the recently submitted draft code of criminal procedure requires the diversion of certain criminal cases to out-of-court mechanisms. This suggests that the presence of organised and well-established out-of-court institutions, which are capable of receiving cases diverted to it by the court or public prosecutor, is essential. However, the draft code neither specifies the nature of such out-of-court mechanisms nor does it indicate what form it should take. Thus, establishing appropriate restorative justice models, by defining and specifying the exact nature of the relevant out-of-court mechanisms, will be the biggest challenge in Ethiopia. 
It is argued elsewhere ${ }^{134}$ that Ethiopia has various customary dispute resolution mechanisms - one form of out-of-court mechanism - which may serve as such models of restorative justice. Since these mechanisms are compatible with the values and principles of restorative justice, though they have no de jure recognition in criminal matters, they can be used as tools to implement restorative justice in the form of diversion either before or after charges are brought. Most of the modern restorative justice programmes in various countries have been shaped by customary or indigenous processes, such as in the case of victim-offender mediation and sentencing circles based on the aboriginal societies of Canada, and family group conferencing based on the Maori tradition in New Zealand. This is mainly because the 'underlying philosophy of indigenous practices that justice seeks to repair the torn community fabric following crime has resonated well with and informed the modern restorative justice ideal. ${ }^{135}$ Similarly, tracing its historical roots, Gavrielides writes that the 'roots of restorative justice practices are ancient, reaching back into the customary practices and religions of most traditional societies though the term restorative justice is coined in the 1970 s. $^{136}$ Seen in that light, the Ethiopian customary dispute resolution mechanisms can be re-organised and institutionalised to implement restorative justice in the Ethiopian criminal justice system, because their philosophy and values are similar to the values and principles of the modern theory and practices of restorative justice. ${ }^{137}$ However, since customary dispute resolution mechanisms are mostly, though not exclusively, vibrant in rural areas, it is necessary to establish other appropriate models of restorative justice (other forms of out-of-court mechanisms) which would fit the urban reality.

Nonetheless, organising and institutionalising such mechanisms requires substantial investment and a real commitment to undertake necessary changes. Above all, establishing restorative justice models presupposes the difficult and challenging task of amending the constitution to include an express provision which recognises out-of-court mechanisms' application to criminal matters. The inclusion of such a constitutional clause will avoid interpretative arguments concerning their status. The absence of such a clause casts a shadow on the validity of diversions of criminal cases. In addition, a detailed and comprehensive study is necessary to find out how to best organise and institutionalise out-of-

134 Enyew, Ethiopian Customary Dispute mechanisms: forms of Restorative Justice?, 14(1) African Journal of Conflict Resolution (2014), pp. 125-154.

135 Van Ness, An Overview of Restorative Justice Around the World, a Paper presented in the $11^{\text {th }} \mathrm{UN}$ Congress on Crime Prevention and Criminal Justice Workshop (Bangkok 2005) p. 2.

136 Gavrielides, Restorative Practices: From the Early Societies to the 1970s, Internet Journal of Criminology (2011), p.3, available at: http://www.internetjournalofcriminology.com/ Gavrielides_Restorative_Practices_IJC_November_2011.pdf (checked 14 Dec. 2014)

137 For a detailed review of the Ethiopian customary dispute resolution mechanisms and their compatibility with the values and principles of modern restorative justice theories and practices, see Enyew, Ethiopian Customary Dispute mechanisms: forms of Restorative Justice?, 14(1) African Journal of Conflict Resolution. (2014), pp. 125-154. 
court mechanisms, particularly so as to define their role, scope and mode of operation, and to demarcate the state's involvement and role in such institutions, to prevent their politicisation. Sufficiently trained mediators working in those out-of-court mechanisms, and who are capable of facilitating the restorative justice process and of extending assistance to the conflicting parties, are also required.

The other important outstanding task is related to the need for a precise law on restorative justice. The recently submitted draft code of criminal procedure should be reframed in a clearer manner by avoiding conceptual confusions, precisely defining its scope of application (i.e. identifying the types of crimes which can be diverted to the restorative justice processes), and taking into account the ongoing discussions, debates and studies before it becomes final and effective law. Alternatively, a separate law on restorative justice is required. This law should provide a detailed guideline on how to make referrals to out-of-court mechanisms, define precisely the nature of the out-of-court mechanisms to which the case will be diverted, regulate the discretionary power of the police, prosecutors, and judges when making referrals, and give guidance to the trained mediators.

Finally, the negative perception given to restorative justice by some actors of the criminal justice system is another challenge that may hinder the effective implementation of restorative justice practices in Ethiopia. In addition to the willingness shown by the government to introduce the new criminal justice policy and to reform the existing criminal procedure code, the willingness of legal practitioners, upon whom the discretion to refer cases rests, is an essential requirement. Where the police, public prosecutors and judges take a strong view in support of punitive rather than restorative approaches to criminal justice, restorative justice options are less likely to be effective. Thus, these key stakeholders' understanding of, and attitude towards, restorative justice options, will have strong impacts on their effectiveness. It is, therefore, an important task to create a conducive environment to improve their understanding of the goals of restorative justice so that become more willing to refer offenders to those programmes.

\section{Conclusion}

Conventional criminal justice systems suffer from extensive limitations. It does not address the needs of crime victims and makes them secondary in the criminal process. It separates the offender from its social ties, it emphasises punishment as an instrument to incapacitate the offender, both as retribution for the current crime and a deterrent to future crimes, instead of taking steps to encourage them to assume responsibility and undo the wrong they have committed. It also gives the state a monopoly over the criminal justice system and excludes community participation in criminal matters by assuming that the community is adequately represented by the public prosecutor. Restorative justice is 
advocated as an alternative way of apprehending crime and serving justice with an aim to complement the criminal justice system and to rectify its limitations.

The current Ethiopian criminal justice system is no exception, and suffers from the aforementioned limitations. Through an analysis of its formal sources, it is shown to focus on the offender's action and puts the emphasis on punishing the offender. Its processes are shown to be disintegrative and stigmatic. The victims are not placed at the centre of the Ethiopian criminal justice system as their role is confined to providing information in the form of accusation or complaint so as to set the justice in motion, or to merely be a witness in their own case upon the discretion of the public prosecutor. In addition, their right to restitution and compensation is not adequately protected, and there is no possibility to bring the victim and the offender together so as to enable them to discuss the causes and consequences of the crime, reconcile, and thereby restore and maintain their peaceful relationships. Similarly, the state has a monopoly on the administration of justice and excludes the community from playing any meaningful role. This shows that the notion of restorative justice is almost non-existent in the current formal Ethiopian criminal justice system, with the exception of some restorative elements, such as the recognition of a limited right of victims and their representatives to claim compensation or otherwise be involved to a limited degree. This is the case when a civil claim can be joined to a criminal trial or by conducting private prosecution if the public prosecutor declines to bring criminal charge against a suspect due to insufficient evidence in the case of crimes that are punishable only upon formal complaint. In some rare cases, the possibility to participate in a reformative process is also offered to the offender by providing parole or probation.

Nonetheless, the government has in recent years shown more willingness to implement restorative justice by presenting a new criminal justice policy and submitting a new draft code of criminal procedure, which provide a general framework and certain promising elements for the implementation of restorative justice by allowing the diversion of certain criminal cases to out-of-court mechanisms, and granting discretionary power to legal practitioners. These documents, if their shortcomings and the challenges facing their implementation are properly addressed, and if the necessary infrastructures are put in place, may serve as important tools to lay the groundwork for restorative justice in the Ethiopian criminal justice system. Generally, while the concept of restorative justice is not yet properly recognised in Ethiopia, there is a great potential for developing restorative justice practices which can meet the needs of its population and reflects its cultural heritage. 